plants have been most important in oriental economics. Among the most important products is agar, which can be made from a number of red seaweeds. In addition to its use as food, agar has come to be indispensable in the textile and leather trades, in making high-grade adhesives, photographic films and shatterproof glass, in medicine and pharmacy and as a medium on which fungi and bacteria can be grown. It is an essential product in all scientific laboratories for culture work, and during the Second World War it was imperative that all countries should have a sufficient supply for the preparation of protective vaccines both for the civilian population and the armed forces. The need was met in different countries in a variety of ways. In Britain an excellent agar was made from two red seaweeds, Chondrus crispus and Gigartina stellata, known collectively as carrageen; these seaweeds were located and harvested mostly by enthusiastic voluntary labour.

Co-operation is needed not only among research workers in many branches of science but also between scientific workers and the commercial world if the best use is to be made of the vast potential resources that are being rhythmically and unceasingly produced in the waters that surround our shores. The work of the surveyor, the engineer, the economist and the manufacturer must be based on the sure foundation of the detailed study of the plants themselves if it is to stand effectively.

$$
12 / 6
$$

\section{THE WIDENING SCOPE OF THE STUDY OF EDUCATION}

$\mathrm{T}$ his presidential address to Section $\mathrm{L}$ (Education), Sir Fred Clarke (remg that it is now better understood how Ow have reached a stage where education has-beckne a major instrument of national policy... Spro light is thrown on the matter, so far as freat Britain is concerned, by a glance back over the last two centuries or so. Two phenomena are particularly noticeable : first, that in both content and methods education was overwhelmingly a matter of tradition; and second, that the golden age of liberalism was also an age of maximum security.

In spite of some variants and breakaways, tradition still ruled even after education had ceased to be selective and had become compulsory for all alike.

The liberalism of the nineteenth century brought less change in this than might have been expected. But it did bring two important contributions. One was science, the other was the idea of the autonomous, self-sufficing individual.

The introduction of science into the curriculum was slowly achieved and very soon it, too, tended to fall under a tradition of its own. Perhaps more important was the application of scientific methods to the study of education itself, and particularly to problems of child-care and teaching.

A growing body of knowledge was the result. But, until recently, the 'individual' was still conceived too abstractly, and the studies took little or no account of the profound changes in social and cultural environment which even then were exerting such influence both upon the growing child and upon his teachers. Persistence of the nineteenth-century notion of the individual is insufficient to account for this. Society and its influences could be so taken for granted because of the peculiar conditions of security that the century enjoyed.
Two influences in particular helped to bring about the changed outlook of our time. One was the thrust of the working-people for wider opportunity, affecting education as it did. The other was that increasing concern for the national future which became so marked towards the end of the century, particularly among the governing classes. It was, perhaps, a fortunate thing that these two influences tended to the same result, an increased concern for general education and a heightened sense of the historical and sociological factors which determined educational thought and practice. Thus there can be little doubt that many of the studies now undertaken were influenced by consideration of the needs of the elementary school, to which the great majority of the population went. The transformation of the elementary school during this century is an achievement that owes much to the new outlook.

To-day we are reaching, if we have not already reached, a conception of education for which little or nothing in the life of society is wholly irrelevant. Studies have broadened out accordingly, and the lengthening of the period of organised educational care has contributed to the same result. Psychology, for example, is concerning itself more and more with the characteristics of adolescence, and social psychology has come into its own.

To illustrate the kind of provision for which this broadened outlook calls, the example of arrangements in the University of London may be cited. At least five essential professorial chairs are now estab. lished, each representing a distinct line of approach. These are : philosophy (the most fundamental of the studies), psychology, history, sociology, and comparative education. As provision along some such lines as these is made in the new university institutes of education throughout Great Britain, it may be expected that stimulating and bracing influences will be brought to bear both upon the work of the schools and upon the training of young teachers for work in them.

If there is any danger that studies may become too detached from actuality, too purely theoretical and self-absorbed, we may hope that the play of informed critical opinion, coming mainly from the schools and colleges but also from an interested public, will supply the necessary corrective.

\section{FARMING, SCIENCE AND EDUCATION} DROF. N. M. CYMBEBlPRris presidential address to Section M gurefture), first deals with the lost appreciation of the status and prestige of farming. In peace fimfond times of plenty, the majority of pepple us their food not merely as necessities of life but a 40 - 6 tokens of goodwill and friendship. Men do 4 to dine together for merely utilitarian purposes; but they are largely oblivious to the reason why the products of the farming industry are used (as the products of no other industry are) to betoken the spiritual as well as the physical well-being of mankind. In times of war, when all minds are on farming, it is the necessity and not the glory of farming which is brought home to everybody. At no time, therefore, in the modern era are the majority of people able to appreciate the status of farming, which lies in the fact that it is inextricably connected with the status of human life itself and is fundamental in a way that no other industry is. In the midst of 